\title{
Exploring the efficacy of silicon supplementation on control of rice grain discoloration disease
}

\author{
Nasla, M F F1, Prasannath $K^{1}$ and Gunapala K R D ${ }^{2}$ \\ ${ }^{1}$ Department of Agricultural Biology, Faculty of Agriculture, Eastern University, Sri Lanka \\ 2Pathology Division, Rice Research and Development Institute, Batalagoda, Sri Lanka
}

\begin{abstract}
Rice is the most important cereal crop in Sri Lanka. Grain discoloration is an emerging disease complex, reducing grain quality of rice crop. Grain discoloration control is, however, mainly focused on fungicide; their use is limited due to perceived environmental problem and health concern. Silicon (Si) application is known as encouraging eco-friendly alternative to fungicide. Foliar applications of Sibased formulations were evaluated to examine their effect on reducing grain discoloration disease. Field experiments were conducted at Rice Research and Development Institute (RRDI), Batalagoda from May to September 2017. After planting, Si was applied as solution at the rate of $1 \mathrm{~mL} / \mathrm{L}$ at tillering and early flowering stage. Fungicide and control (sterilized water) were applied as treatments at early flowering stage. Treatments were arranged in a randomized complete block design with three replications. Data on plant height, total number of tillers per plant, chlorophyll content, yield, incidence of plant infection and percentage of grain discoloration were recorded. Laboratory study was carried out to isolate and identify the grain discoloration causing pathogens from the infected seeds by using potato dextrose agar plate method. Results revealed that incidence of plant infection and grain discoloration percentage were reduced by foliar application of silicon supplements as same as fungicide application. Among the Si-based formulations tested, Gainexa UPL gave the best result in controlling grain discoloration in rice. These silicon supplements could be used as alternatives to synthetic fungicide and could reduce the amount of fungicide needed during rice crop cultivation. Curvularia lunata and Curvularia pallescence were identified as the causal organisms of rice grain discoloration disease in the study area.
\end{abstract}

Keywords: Grain discoloration, Rice, Silicon supplements, Synthetic fungicide

\section{Introduction}

Rice is one of the most important cereal food crops in the world. It is consumed as a staple food and it provides more than one fifth of the calories in the world for human consumption (Arshad et al., 2009). Rice is also a single staple food in Sri Lanka. The average per capita consumption of rice in Sri Lanka is $114 \mathrm{~kg}$ per year per person (Roberia et al., 2014). About 1.8 million farm families are engaged in paddy cultivation in island-wide (Rodrigo, 2014). However, rice crop is threatened by different biotic and abiotic factors. Rice crop is threatened by more than 50 diseases which may appear at any growth stage of the plant (Arshad et al., 2009). The quality of rice is directly affected to marketable yield and consumption of rice grain. Grain discoloration disease is an emerging disease complexes threaten for rice crop seriously. Grain discoloration reduces 
grain quality very seriously and also reduces consumer preference on rice (Phat et al., 2005). Du et al. (2001) reported that grain discoloration affected milling recovery, cooking and eating quality, seed germination and seedling height.

There are several reasons to cause the grain discoloration on rice crops such as panicle lodging, soil and climate changes, and microbial infection. Among these reasons, microbial infection is the major reason for the rice grain discoloration disease (Agarwal et al., 1989). It occurs due to the infection of microorganisms on the glumes, kernel or both (Ou, 1985; Arshad et al., 2009). A large number of fungi and bacteria is associated with rice grain discoloration disease $(\mathrm{Ou}, 1985)$. The fungi that are reported to be associated with discoloration of grains are Bipolaris oryzae, Alternaria padwickii, Pyricularia oryzae, Fusarium moniliforme, Fusrium grminearum, Nigrospora oryzae, , Curvularia spp, Phoma sorghina, Dichotomophthoropsis nymphacearum and Heterosporium echinunulatum etc. (Ou, 1985; Arshad et al., 2009). Suryadi and Kadir (2009) reported that several bacteria such as Pseudomonas avenae, Pseudomonas fuscovaginae, Pseudomonas syringae var. oryzicola, and Pseudomonas glumae could cause rice grain discoloration disease.

Most of the studies showed that seed treatment with synthetic fungicides and foliar application of synthetic fungicide are most effective to control rice grain discoloration disease (Agarwal et al., 1989; Arshad et al., 2009). However, continuous use of fungicides can lead to health and environmental problems (Korndorfer et al., 1999) and development of fungicide resistance of pathogen populations (Jayawardana and Weerahewa, 2016). Therefore, to address the current demand in sustainable crop production and concern of food safety, environmental friendly alternatives should be investigated to control rice grain discoloration disease.

Silicon (Si) application may offer an encouraging alternative to fungicide use while enhancing host plant resistance (Datnoff et al., 1997; Korndorfer et al., 1999). Si is beneficial for plants in terms of yield (Ghasemi et al., 2013), growth and resistance to biotic and abiotic stresses (Datnoff et al., 1992). Addition of Si can decrease the incidence of several diseases in rice such as blast, brown spot, sheath blight, grain discoloration and disease bacterial leaf blight (Jayawardana and Weerahewa, 2016).

Various mechanisms have been proposed to explain the increased level of disease resistance mediated by Si. It acts as a physical barrier, deposited beneath the cuticle, to impede penetration by fungal appressoria, thereby disrupting the process of infection (Jayawardana et al., 2015). Si may signal a biochemical mechanism to suppress fungal infection and disease (Weerahewa and Somapala, 2016). Si could induce defense responses such as systemic acquired resistance (Jayawardana and Weerahewa, 2016). Hence, inorganic form of Si would be used as solution form to spray on the plant. The bioactive form of silicon (orthosilicic acid) would be provided to plant as foliar spray to enhance the plant resistance against the rice grain discoloration. Therefore, the present study was conducted to determine the effect of silicon supplements on rice grain discoloration disease and identify the pathogens causing rice grain discoloration disease in the research area. 


\section{Materials and Methods}

\subsection{Evaluation of the effect of silicon supplements on control of grain discoloration}

A field experiment was carried out at the Rice Research and Development Institute (RRDI), Batalagoda, Sri Lanka, during Yala season from May to September 2017. The following five treatments with three replications were arranged in Randomized Complete Block Design. Treatments include three different silicon supplements, a synthetic fungicide and sterilized water. Bg 370 variety was selected as object for the field trial because more seed discoloration has been observed in Bg 370 variety in Batalagoda.

$\mathrm{T}_{1}$ - Sterilized water (Control)

$\mathrm{T}_{2}$ - Silicon 1 (Orthosilicic Acid in liquid form - Silicon solution)

$\mathrm{T}_{3}$ - Silicon 2 (Orthosilicic Acid in liquid form - Imported sample (Gainexa UPL))

$\mathrm{T}_{4^{-}}$Silicon 3 (Sodium metasilicate in Solid form (Silicon 17))

$\mathrm{T}_{5}$ - Fungicide (Azoxystrobin $200 \mathrm{~g} / \mathrm{L}+$ Cyproconazole $80 \mathrm{~g} / \mathrm{L} \mathrm{SC}$ fungicide)

\subsection{Establishment of rice seedlings in the field}

Healthy seeds of Bg 370 variety were seeded at parachute nursery bed. The seedlings were kept for 12 days in nursery bed. After 12 days, selected healthy seedlings were established in the field. Before the establishment of rice seedlings, the field was divided into 15 plots. Each plot area was $18 \mathrm{~m}^{2}$. One meter spacing was maintained within the plots. Fertilizers were applied according to the recommendation of the Department of Agriculture, Sri Lanka. The field was irrigated regularly. Weed control was done manually and the field sanitation was also maintained. All plots were allowed for the natural infestation of grain discoloration pathogens.

\subsection{Preparation and application of treatments}

Test solutions of the Si supplements were prepared according to the label instructions. They were prepared at 1 $\mathrm{mL} / \mathrm{L}$ concentration (1 ppm). Si supplements were applied two times during the crop life cycle. First application of $S i$ supplements was done 40 days after transplanting (tillering stage or just before the booting stage). Second application was done 70 days after transplanting (at early flowering stage of the plant). The fungicidal solution was prepared at the concentration of $1 \mathrm{~mL} / \mathrm{L}$ ( $1 \mathrm{ppm})$. It was applied 70 days after transplanting (at early flowering stage of rice plant).

\subsection{Isolation and identification of pathogens causing grain discoloration}

The laboratory experiment was carried out at the Pathology Laboratory of RRDI. Potato dextrose agar plate method was used to isolate the pathogens from infected grains. The discolored seeds of $\mathrm{Bg} 370$ were collected by using random sampling method from each plot in the field. They were mixed thoroughly. From the seed lot, 50 discolored seeds were randomly collected. The seeds were kept under the running tap water for 30 minutes. After prewashing of seeds, 25 seeds were directly planted on the potato dextrose agar plates. Five seeds were planted on each agar plate. Another 25 seeds were surface sterilized by using $70 \%$ of ethanol for 1 minute. The surface sterilized seeds were thoroughly washed with distilled water three times. The sterilized 5 seeds were planted on each plate. Three days after planting of seeds in agar plates, clearly observed colonies of fungi 
which were grown surrounding the planted seeds on agar plates were subcultured. The sub-culturing of fungal colonies was continued until getting pure cultures of fungal colonies for clear identification. After getting the pure cultures of pathogens, characters
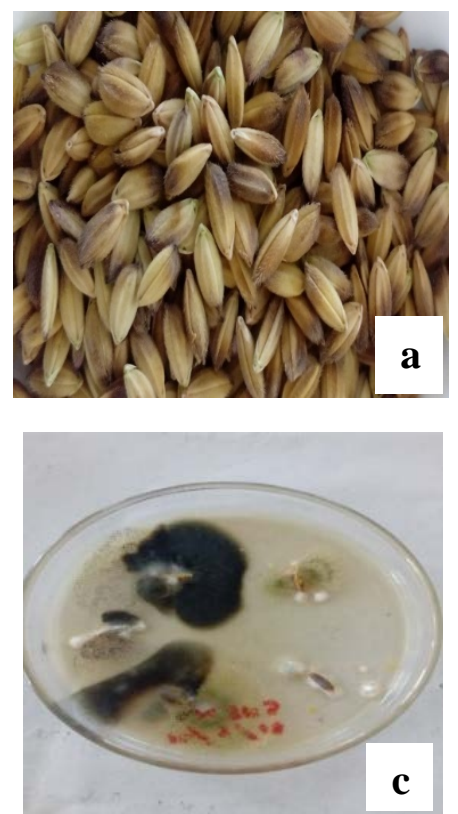

of fungal colonies were observed to identify the pathogens. Later, microscopic examination was performed to confirm the pathogens on the basis of mycelial growth and spore shape morphology (Fig. 1).
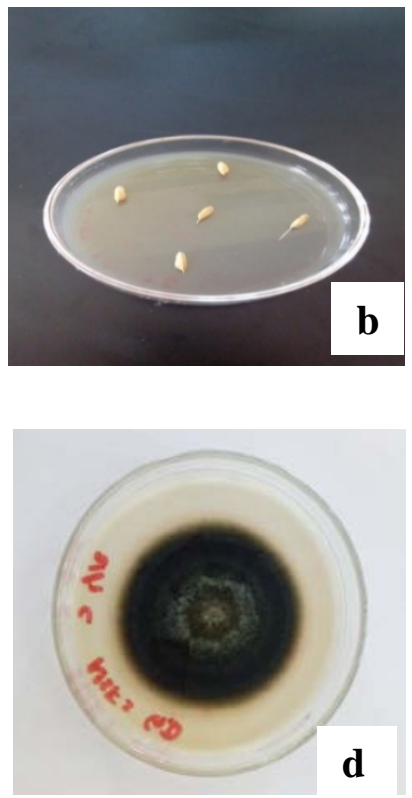

Fig.1. a) Discolored seeds b) Planting the seeds on PDA plate c) Fungal growth surrounding the seeds $\mathrm{d}$ ) Pure culture of fungal pathogen

\subsection{Data collection and analysis}

Data were collected from sampled plants selected by quadrant method from each replicate of each treatment. The quadrant method was done 5 times per plot. Plant height, chlorophyll content of leaves and total numbers of tillers per plant were measured at maximum tillering stage (70 days after transplanting). The yield was determined from the total plants in each plot of each treatment at harvesting stage (106 days after transplanting). Percentage of infected plants was determined at ripening stage (95 days after transplanting) using the following formula. A plant with at least $50 \%$ of grains showing discoloration was considered as an infected plant (IRRI, 2014).

Percentage of
infected plants $=$ $\begin{aligned} & \begin{array}{l}\text { Number of infected } \\ \text { plants } \times 100 \%\end{array} \\ & \begin{array}{l}\text { Total number of } \\ \text { sampled plants per } \\ \text { plot }\end{array}\end{aligned}$

Percentage of discolored grains was estimated using the following equation. Grain discoloration was estimated by counting grains with more than $25 \%$ of glume surface affected (IRRI, 2014).

$$
\begin{array}{ll}
\begin{array}{l}
\text { Percentage of } \\
\text { discolored } \\
\text { grains }=
\end{array} & \begin{array}{l}
\text { Number of } \\
\text { discolored seeds } \times
\end{array} \\
& \begin{array}{l}
\text { To0\% } \\
\text { Total number of } \\
\text { seeds in } 25 \mathrm{~g} \text { of seed } \\
\text { lot }
\end{array}
\end{array}
$$

Arc-sin transformation technique was used to transform the non-parametric data such as percentages of infected plants and discolored grains, which 
were then confirmed normally distributed by performing normality test. Data were subjected to Analysis of Variance and the significance of treatments was tested using Duncan's Multiple Range Test at $\mathrm{a}=0.05$ level.

\section{Results and Discussion}

3.1 Evaluation of foliar application of silicon on rice grain discoloration disease

Height of rice plants was not significantly $(\mathrm{p}>0.05)$ affected by silicon supplements and fungicidal application (Table 1). In the investigation, no significant differences were observed between silicon treated and deprived rice plants in term of plant height confirming the reports by Liang et al. (2005), Guevel et al. (2007) and Guntzer et al. (2012). Liang et al. (2005) stated that silicon has not been considered important for vegetative growth but it aids the plant in healthy development under stresses in different grasses especially in rice. Guevel et al. (2007) found that Si feeding did not yield a direct measurable effect on plant growth. In their experiments, $\mathrm{Si}$ amendment, either through the roots or the leaves did not increase growth of wheat plants. Si, an element forming up to $60 \%$ of the wheat ash had no metabolic role in wheat plant

There were no significant $(p>0.05)$ differences observed among the treatments in the total number of tillers per rice plant at the maximum tillering stage (Table 1). In the investigation, no significant differences were observed between silicon tested and deprived rice plant in term of number of tillers per plant. These results are in line with Ahmed et al. (2013), who reported that increase in applied silicon amount did not enhance the number of tillers per plant in rice.
Chlorophyll content rice plant was not significantly $(\mathrm{p}>0.05)$ affected by silicon supplements and fungicide application (Table 1). In the investigation, no significant differences were observed among silicon treated, fungicide treated and deprived rice plant in the term of chlorophyll content. These results are in accordance with the finding of Bhalali et al. (2013) reporting that there was no significant correlation between chlorophyll a and logarithm chlorophyll a with silica in wetland plants.

Yield of rice plants was significantly $(p<0.05)$ affected by silicon supplements and fungicidal application compared to control (Table 1). $\mathrm{Si}$ supplements and fungicidal application resulted in a similar effect on yield of rice grains as there were no significant $(p>0.05)$ differences between the $\mathrm{Si}$ supplements and fungicidal solution. This result was obtained because fungicide which has the ability to reduce the disease to the same general degree as silicon could reduce the severity of disease and increase yield in rice plants. Rodrigues et al. (2010) reported that the severity of leaf angular disease in beans was reduced by fungicide application, through that increased the yield of beans. In the investigation, significantly higher $(p<0.05)$ yield was observed in $\mathrm{Si}$ treated plants compared to the control plants, confirming the reports by Soratto et al. (2011) and Ahmed et al. (2013). Soratto et al. (2011) showed that grain yield was significantly increased by $\mathrm{Si}$ leaf application compared to the control (without $\mathrm{Si}$ application), as a result of the higher photosynthetic area, due to the higher dry matter production and higher number of spikes per $\mathrm{m}^{2}$ in white oat and wheat. Ahmed et al. (2013) demonstrated that foliar application of silicon solution significantly increased paddy yield 
compared to control (without silicon

application).

Table 1. Effect of silicon supplements and fungicide application on incidence of plant infection and discoloration grains

\begin{tabular}{lcccc}
\hline Treatments & $\begin{array}{c}\text { Plant height } \\
(\mathbf{c m})\end{array}$ & $\begin{array}{c}\text { Number of } \\
\text { tillers per plant }\end{array}$ & $\begin{array}{c}\text { Chlorophyll } \\
\text { content (SPAD) }\end{array}$ & $\begin{array}{c}\text { Yield per } \\
\text { plot (kg) }\end{array}$ \\
\hline Control & $102.71 \mathrm{a}$ & $10.92 \mathrm{a}$ & $37.55 \mathrm{a}$ & $6.10 \mathrm{~b}$ \\
Silicon 1 & $98.67 \mathrm{a}$ & $10.29 \mathrm{a}$ & $39.71 \mathrm{a}$ & $10.17 \mathrm{a}$ \\
Silicon 2 & $98.35 \mathrm{a}$ & $11.72 \mathrm{a}$ & $38.56 \mathrm{a}$ & $9.38 \mathrm{a}$ \\
Silicon 3 & $100.14 \mathrm{a}$ & $11.21 \mathrm{a}$ & $40.16 \mathrm{a}$ & $10.03 \mathrm{a}$ \\
Fungicide & $100.80 \mathrm{a}$ & $10.24 \mathrm{a}$ & $39.43 \mathrm{a}$ & $8.80 \mathrm{a}$ \\
\hline
\end{tabular}

Values are means of three replicates.

Mean values with similar letter are not significant at $\alpha=0.05$.

There were significant $(\mathrm{p}<0.05)$ differences observed among the treatments in the percentage of infected plants (Table 2). The result revealed that percentage of infected rice plants was significantly affected by silicon supplements and fungicidal application compared to control. The application of Si foliar sprays caused a significant reduction $(\mathrm{p}<0.05)$ in percentage of infected plants compared to plants receiving control treatment. Si-based products such as silicon 2 and 3 resulted in a similar disease control as the fungicidal solution but Silicon 1 treatment did not show the better performance on the disease incidence compared to the other $\mathrm{Si}$ based products and fungicidal solution. In present experiment, all three Si-based products applied as a foliar solution did not perform equally. Silicon 2 and 3 were as equally-capable as fungicide application for controlling the disease.
There were significant $(\mathrm{p}<0.05)$ differences found among the treatments in the discoloration percentage of grains (Table 2). The result revealed that the discoloration percentage of grains was significantly affected by silicon supplements and fungicidal application compared to the control. The application of $\mathrm{Si}$ foliar sprays caused a significant reduction of grain discoloration compared to plants receiving control treatment. There were no significant $(\mathrm{p}>0.05)$ differences between Silicon 1, Silicon 3 and fungicide application, but Silicon 2 significantly reduced $(p<0.05)$ grain discoloration compared to the fungicide. Si-based products resulted in a similar disease control as the fungicidal solution but Silicon 2 treatment showed the better performance in control of disease than the other Si-based products and fungicidal solution. 
Table 2. Effect of silicon supplements and fungicide application on incidence of plant infection and discoloration grains

\begin{tabular}{lcc}
\hline Treatments & $\begin{array}{c}\text { Percentage incidence } \\
\text { of plant infection (\%) }\end{array}$ & $\begin{array}{c}\text { Percentage } \\
\text { of discolored grains (\%) }\end{array}$ \\
\hline Control & $78.21 \mathrm{a}$ & $8.12 \mathrm{a}$ \\
Silicon 1 & $54.96 \mathrm{~b}$ & $4.42 \mathrm{~b}$ \\
Silicon 2 & $43.04 \mathrm{c}$ & $3.75 \mathrm{c}$ \\
Silicon 3 & $42.49 \mathrm{c}$ & $4.07 \mathrm{~b}$ \\
Fungicide & $30.95 \mathrm{c}$ & $4.15 \mathrm{~b}$ \\
\hline
\end{tabular}

Values are means of three replicates.

Mean values with similar letter are not significant at $\alpha=0.05$.

Role of silicon in plant health has been investigated in silicon accumulating crops and it seemed significantly effecting (Jinab et al., 2008). Research evidences proved that adequate uptake of silicon can increase the tolerance of agronomic crops especially rice to both abiotic and biotic stress (Ma and Takahashi, 2002). It has been reported in previous studies that application of silicon materials and silicon-based fertilizers such as potassium silicate; sodium silicate and silica gel improved growth and yield of rice plants as well as enhanced plant resistance against biotic and abiotic stresses (Belanger et al., 1995; Datnoff et al., 1997; Seebold et al., 2001). In the present study, the results showed that application of silicon supplements effectively reduced the incidence of rice grain discoloration. These results further confirm previous reports by Korndorfer et al. (1999), Seebold et al. (2000) and Prabhu et al. (2001). Korndorfer et al. (1999) showed that the influence of silicon on rice grain discoloration in Brazil. They reported that application of wollastine (source of silicon) increase the plant available $S i$ in the soil dramatically reduced rice grain discoloration disease in Brazil. Seebold et al. (2000) reported that increased level of $\mathrm{Si}$ in the rice plant is associated with decreased level of grain discoloration at harvest. Prabhu et al. (2001) showed that the severity of grain discoloration disease in several irrigated and upland rice genotype decreased by $\mathrm{SiO}_{2}$, amending to the soil increased.

Foliar application of Si-based products has been proved to reduce the disease severity and incidence in plants by some studies. Ashtiani et al. (2012) demonstrated that foliar application of Si reduced disease severity and disease incidence of blast disease in rice. Foliar application of $\mathrm{Si}$ has been reported to be effective in inhibiting powdery mildew development on cucumber, muskmelon and grape leaves (Bowen $e t$ al., 1992; Ma, 2004). Studies showed that Si supplied via leaf application, at lower rates, can be a viable alternative to provide this nutrient to plants, with particular beneficial effects, meeting the $\mathrm{Si}$ requirements and/ or stimulating Si uptake (Figueiredo et al., 2010; Sousa et al., 2010). Ma and Yamaji (2006) reported that $\mathrm{Si}$ applied to leaves deposit on the surface of the leaves and play a similar role to that of Si taken up from the roots.

\subsection{Identification of causal organisms of grain discoloration disease in Batalagoda}

Two species of genus Curvularia were identified as causative agents of rice grain discoloration disease in Batalagoda area. Curvularia lunata and Curvularia pallescence were isolated from the discolored seeds. Curvularia 
pallescens and Curoularia lunata have been identified as causal agents of grain discoloration in rice by $\mathrm{Ou}$ (1985) whereas Curvularia lunata has been reported as causative agent of rice grain discoloration by Kato et al. (1988)

\section{Curoularia lunata}

Macroscopic features showed that colony characters resemble with the original description of Curvularia lunata by $\mathrm{Ou}(1985)$ and Mew and Gonazales (2002). Colonies on PDA at $28-30{ }^{\circ} \mathrm{C}$ grew fast and attained an $8.40 \mathrm{~cm}$ diameter in 5 days. Colonies were zonated and felted; the conidial area was greenish gray with a $3 \mathrm{~mm}$ sterile advancing margin and abundant grayish mycelial tufts (Fig.2 c). The colony appearance on the reverse side of the agar plate was zonated and gray
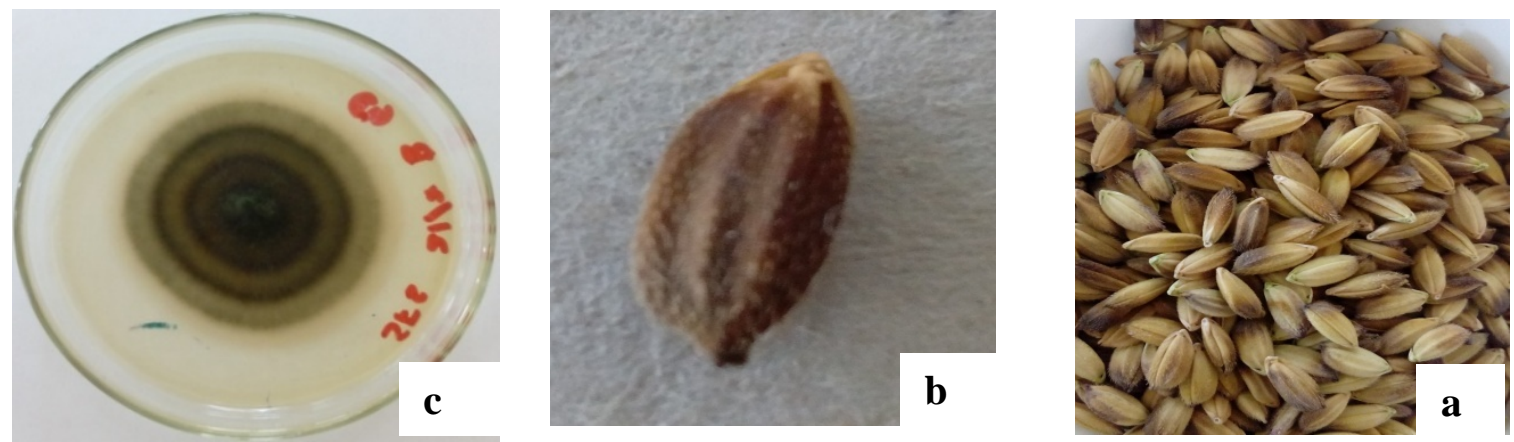

Fig.2. a) Discolored rice seeds b) Fully discolored single rice seed c) Curvularia lunata on PDA media

Microscopic features showed the original spore and mycelial characters of Curvularia lunata described by $\mathrm{Ou}$ (1985) and Mew and Gonazales (2002). Mycelia were septated, branched, subhyaline to light brown. Conidiophores were dark brown, unbranched, septated, sometimes bent and knotted at the tip. Conidia was dark brown, boat-shaped, rounded at the tip, mostly a little constricted at the base; with hilum scarcely or not at all protuberant, smooth walled, light to dark brown, with three septa; the $2^{\text {nd }}$ cell was larger than the $1^{\text {st }}, 3^{\text {rd }}$, and $4^{\text {th }}$ cells; bent on the $2^{\text {nd }}$ cell; borne at the tip, arranged in a whorl one over another or more or less spirally arranged or in thick panicles (Fig. 3).

\section{Curvularia pallescence}

Macroscopic features resemble the original colony characters of Curvularia pallescence described by Freire et al. (1998). Cultures of C. pallescens developed on PDA showed that colonies were effuse gray in color, becoming black when older, black on the backside, presented slightly irregular borders and cottony growth with concentric zones (Fig. 4 c).

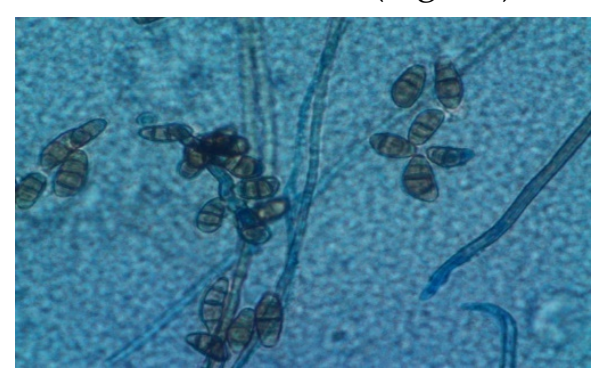

Fig.3. Curoularia lunata mycelia, conidiophores and conidia $(40 \times 10)$ 

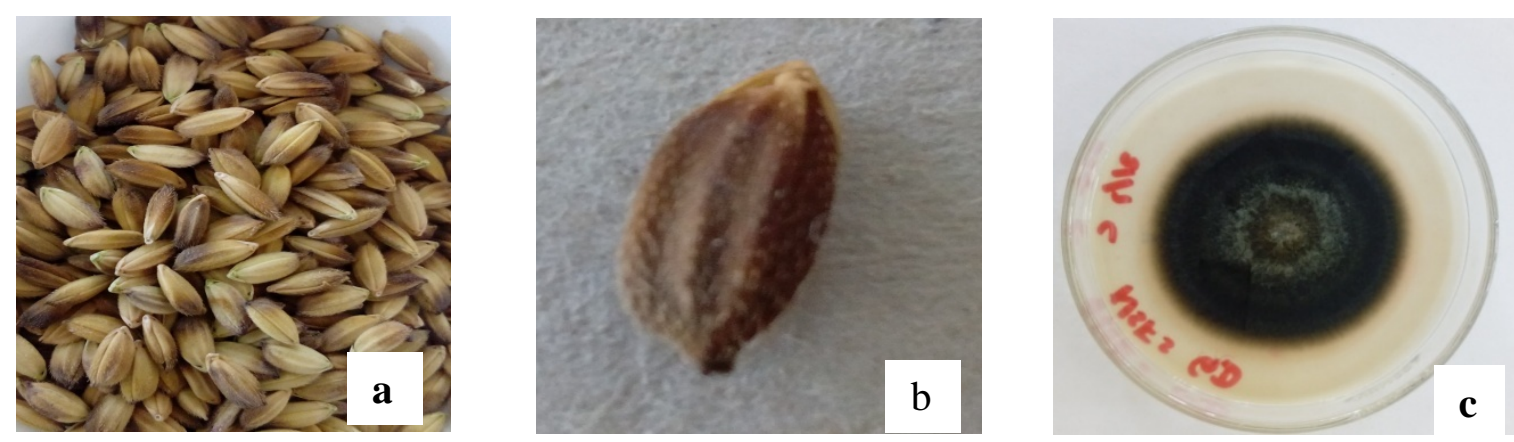

Fig. 4 a) Discolored rice seeds b) Fully discolored single rice seed c) Curvularia pallescence on PDA media

Microscopic features showed the original spore and mycelial characters of Curvularia pallescens described by $\mathrm{Ou}$ (1985) and Freire et al. (1998). Conidia were slightly curved, three septate, with the medium septum somewhat off-center. In general, central cells were broader and darker than the end cells. Some mature conidia were slightly collapsed after being liberated from the conidiophores. Mycelium was mostly immersed, forming straight or flexuous. The conidiogenous cell was broader at the apex and seemed to be inflated at first, with sympodial formation of conidia (Fig. 5).

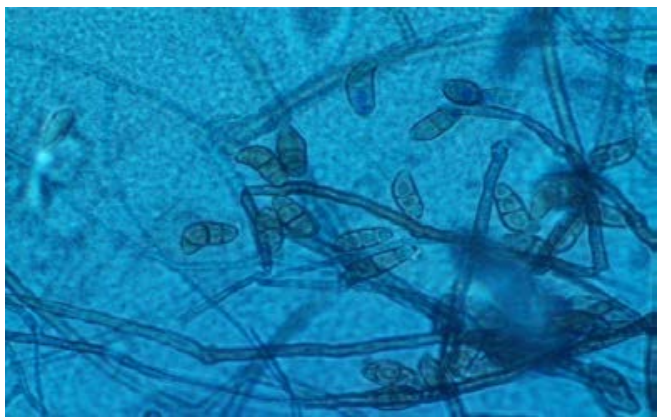

Fig. 5 Curvularia pallescens mycelia, conidiophores and conidia $(40 \times 10)$

\section{Conclusions}

In the present study, two different Curoularia spp. namely Curoularia lunata and Curvularia pallescens were isolated and identified as the causal agents of rice grain discoloration disease in Batalagoda area. The findings of the study revealed that Si-based formulations had the ability to reduce the grain discoloration disease in rice. Among the tested silicon supplements, Gainexa UPL (Orthosilicic acid) gave the best result in term of suppression of rice grain discoloration than the other silicon supplements. Silicon application did not yield a direct measurable effect on plant height and chlorophyll content, but showed considerable effect on yield. Silicon foliar application controlled the disease to the same general degree as a fungicide, thereby, can reduce the amount of fungicide needed. Therefore, it could be an alternative viable method to synthetic fungicide application.

\section{References}

Agarwal, P.C., Mortensen, C.N. and Mathur, S.B (1989). Seed borne diseases and Seed health esting of rice. Danish Institute of Seed Pathology for Developing countries. Technical bull. No 3. 106.

Ahmad, A., Afzal, M., Ahmad, A.U.H. and Tahir, M. (2013). Effect of foliar application of silicon on yield and quality of rice (Oryza sativa L). Cercetări Agronomice în Moldova, XLVI(3):155.

Arshad, H.M.I., Khan, J.A, Naz, S., Khan, S.N. and Akram, M. (2009). Grain Discoloration Disease complex: A New threat for rice crop and Management. 
Pakistan Journal of Phytopathology, 21(1): 31-36.

Ashtiani, F.A., Kadir, j.B., Selamat, A.B., Hanif, A. H. B.M. and Nasehi, A. (2012). Effect of Foliar and Root Application of Silicon Against Rice Blast Fungus in MR219 Rice Variety. Plant Pathology Journal, 28(2): 164-171.

Belanger, R. R., Bowen, P. A., Ehret, D. L., and Menzies, J. G. (1995). Soluble silicon: its role in crop and disease management of greenhouse crops. Plant Disease, 79:329-336.

Bhalali, S., Hoseini, S.A., Ghorbani, R., and Kordi, H. (2013). Relationship between nutrient and chlorophyll a concentration in the international Alma Gol wetland, Iran. Journal Aquatic Research Development, 4 (3): An open access journal.

Bowen, P. A., Menzies, J. G. and Ehret, D. L. (1992). Soluble silicon sprays inhibit powdery mildew development on grape leaves. Journal of the American Society for Horticultural Science, 117:906912.

Datnoff, L.E., Snyder, G.H. and Deren, C.W. (1992). Influence of silicon fertilizer grades on blast and brown spot development and yields of rice. Plant Disease, 76:1011-1013.

Datnoff, L.E., Deren, C.W. and Snyder, G.H. (1997). Silicon fertilization for disease management of rice in Florida. Crop protection, 16:525-531.

Du, P.V., Loan, L.C., Cuong, N.D, Nghiep, H.V. and Thach, D.N. (2001). Survey on seed borne fungi and its effects on grain quality of common rice cultivars in the Mekong Delta. Omon rice, 9:107-113.

Figueiredo, F.C., Botrel, P.P.; Teixeira, C.P., Petrazzini, L.L., Locarno, M. and Carvalho, J.G. (2010). Pulverização foliar e fertirrigação com silício nos atributos físico-químicos de qualidade e índices de coloração do morango. Ci. Agrotec., 34:1306-1311.

Freire, S.V.P., Paiva, L.M., Lima, E.A.D.L. and Maiz, L.S. (1998). Morphological, cytological, and cultural aspects of curvularia pallescens. Review Microbiology, 29(3).

Ghasemi, A., Ejraei, A. and Rajaei, M. (2013) Effect of silicon on vegetative and generative performance of Borad Bean (Vicia faba L.) Journal of Novel Applied Science, 2(S):881-884.

Guevel, M.H., Menzies, J.G. and Belanger, R.R. (2007). Effect of root and foliar applications of soluble silicon on powdery mildew control and growth of wheat plants. European Journal, Plant Pathology, Springer.

Guntzer, F., Keller, C. and Meunier, J.D. (2012). Benefits of plant silicon for crops: a review. Agronomy Sustainable Development, 32(1):201-213.

IRRI, 2014. Standard Evaluation System for Rice, $4^{\text {th }}$ Edition. Manilla, International Rice Research Institute, Philippines.

Jayawardana, H.A.R.K. and Weerahewa, H.L.D. (2016). Soil amendment with raw rice hull as a source of silicon in enhancing anthracnose disease resistance, plant growth and fruit qualities of chili pepper (Capsicum annum L.) Ruhuna Journal of Science, 7:64-69.

Jayawardana, H.A.R.K., Weerahewa, H.L.D. and Saparamadu, M.D.J.S. (2015). Enhance resistance to anthracnose disease in chilli pepper (Capsicum annuum L.). Journal of Horticultural Science and Biotechnology, 90(5):557-562.

Jinab, H., Solond, M., Varietel, M. (2008). Functional food product development. Book. 354. Published by Smith \& Charter.

Kato, H., Ohata, K., Kauraw, L.P., and Lee, Y.H. (1988). Fungal diseases of rice 
seed. pp. 151-162. In: Rice seed health. International Rice Research Institute, Manilla, Philippines.

Korndorfer, G.H., Datnoff, L.E. and Correa, G.F. (1999). Influence of silicon on grain discoloration and upland rice growth in four Savanna soils in Brazil. Journal Plant nutrients, 22: 53-102.

Liang, Y.C., Sun, W.C. and Si, J. (2005). Effects of foliar-and root-appliedsilicon on the enhancement of induced resistance to powdery mildew in Cucumis sativus. Plant Pathology, 54:678-685.

Ma, J.F. (2004). Role of silicon in enhancing the resistance of plants to biotic and abiotic Stresses. Soil science and Plant nutrient, 50(1): 11-18.

Ma, J.F. and Takahashi, E. (2002). Soil fertilizer and plant silicon research in Japan. Elsevier Science, Amsterdam.

Mew, T.W. and Gonzales, P. (2002). A hand book of rice seed borne fungi. International rice Research Institute, Los Banos, Philippines and Enfield, N.H., USA. Science publishers Inc. 83.

Ou, S.H. (1985). Rice Diseases, CAB International Mycological, Institute Kew survey, UK. 380.

Phat, C.T, Duong, T.N, Du, L.T. (2005). Influence of Grain Discoloration To seed Quality. Omon rice, 13:139-144.

Prabhu, A.S., Barbosa filho, M.P., Filippi, M.C., Datnoff, L.E. and Snynder, G.H. (2001). Silicon from rice disease control perspective in Brazil. In: Silicon in Agriculture. L. E. Datnoff, G. H. Snyder, and G.H. Korndofer (eds). Studies in Plant Science. Elsevier Science B. V., Amsterdem, The Nethar lands.

Roberia, S.P., Wickramasinghe, H.A.M., Samarasinghe, W.L.G. and Prashanth, B.D.R. (2014). Diversity of grain quality characteristics of traditional Rice (Oryza sativa L.) Varieties in Sri Lanka. Tropical Agriculture Research, 25(4):570-578.

Rodrigo, C. (2014). Key Determinants of Sri Lanka's fertilizer subsidy: Some research findings for policy makers. Talking Economics. Institute of Policy Studies of Sri Lanka, Sri Lanka.

Rodrigues, F.A., Duarte, H.S.S., Rezende, D.C., Wordell Filho, J.A., Korndorfer, G.H. and Zambolim, L. (2010). Foliar spray of potassium silicate on the control of angular leaf spot on beans. Journal of Plant Nutrition, 33:2082-2093.

Seebold, K.W., Datnoff, L.E., CorreaVictoria, F.J., Kucharek, T.A., and Snyder, G.H. (2000). Effect of silicon rate and host resistance on blast, scald, and yield of upland rice. Plant Disease, 84:871-876.

Seebold, K.W., Kucharek, T.A., Datnoff, L.E., Correa-Victoria, F.J., and Marchetti, M.A. (2001). The influence of silicon on components of resistance to blast in susceptible, partially resistant, and resistant cultivars of rice. Phytopathology, 91:63-69.

Soratto, R.P., Crusciol, C.A.C., Castro, G.S.A., da Costa, C.H.M. and Neto, J.F. (2011). Leaf application of silicic acid to white oat and wheat. R. Bras. Ci. Solo, 36:1538-1544.

Sousa, J.V., Rodrigues, C.R., Luz, J.M.Q., Sousa, V.B.F.; Carvalho, P.C., Rodrigues, T.M. and Brito, C.H. (2010). Silicato de potássio via foliar no milho: Fotossíntese, crescimento e produtividade. Bioscience Journal, 26:502-513.

Suryadi, Y. and Kadir, T.S. (2009). Effect of Longevity of Seedling-inoculation with Trichoconis padwickii on the severity of rice grain discoloration. Journal Agrotropika, 14(1):9-14.

Wang, S.Y. and Galleta, G.J. (1998). Foliar application of potassium silicate induces metabolic changes in strawberry plants. Journal of Plant Nutrient, 21:157-167.

Weerahewa, D. and Somapala, K. (2016). Role of Silicon on enhancing disease resistance in Tropical fruits and Vegetable. A Review of OUSL Journal, 11:13 -162. 